\title{
Video NeuroImages: Head titubation in anti-mGluR1 autoantibody-associated cerebellitis
}

José Luiz Pedroso, MD, PhD, Lívia Almeida Dutra, MD, PhD, Alberto J. Espay, MD, MSc, Romana Höftberger, MD, and O.G.P. Barsottini, MD, PhD

Neurology ${ }^{\circledR}$ 2018;90:746-747. doi:10.1212/WNL.0000000000005338

A 39-year-old woman presented with apathy, catatonia, and continuous large-amplitude oscillatory head movements (head titubation) evolving over 1 month (video, links.lww.com/ WNL/A353). Severe ataxia developed weeks later. Brain MRI, EEG, and serologies were normal. Cell- and tissue-based assays were positive for anti-metabotropic glutamate receptor 1 (mGluR1) antibodies (serum 1:12,800, CSF 1:512; figure). Head titubation, a slowfrequency cerebellar outflow tremor of the head associated with axial hypotonia, may appear in cerebellar abnormalities (Joubert syndrome, Dandy-Walker syndrome) or disorders affecting the anterior lobe of the cerebellum. ${ }^{1}$ Subacute head titubation should raise suspicion for an mGluR1-associated autoimmune cerebellitis, especially if associated with psychiatric changes. $^{2}$

\section{Author contributions}

J.L. Pedroso: case report project conception, organization, execution; writing of the first draft, review and critique. L.A. Dutra: case report project conception, organization, execution; writing of the first draft, review and critique. A.J. Espay: writing of the first draft, review and critique. R. Hoftberger: case report project execution; writing of the first draft, review and critique. O.G. Barsottini: writing of the first draft, review and critique.

\section{Study funding}

No targeted funding reported.

\section{Disclosure}

J. Pedroso and L. Dutra report no disclosures relevant to the manuscript. A. Espay has received grant support from the NIH, Great Lakes Neurotechnologies, and the Michael J. Fox Foundation; personal compensation as a consultant/scientific advisory board member for AbbVie, TEVA, Impax, Acadia, Acorda, Cynapsus/Sunovion, Lundbeck, and USWorldMeds; publishing royalties from Lippincott Williams \& Wilkins, Cambridge University Press, and Springer; and honoraria from AbbVie, UCB, USWorldMeds, Lundbeck, Acadia, the American Academy of Neurology, and the Movement Disorders Society. R. Hoftberger received grant support from the Jubilaeumsfonds der Oesterreichischen Nationalbank, project 16919. O. Barsottini reports no disclosures relevant to the manuscript. Go to Neurology.org/ $\mathrm{N}$ for full disclosures.

\section{References}

1. Zanni G. Head titubation: an unrecognized manifestation of Joubert syndrome and other (midline) cerebellar disorders? Dev Med Child Neurol 2014;56:925-926.

2. Lopez-Chiriboga AS, Komorowski L, Kümpfel T, et al. Metabotropic glutamate receptor type 1 autoimmunity: clinical features and treatment outcomes. Neurology 2016;86:1009-1013.
Correspondence

Dr. Dutra

liviaadutra@hotmail.com

\section{MORE ONLINE}

$\rightarrow$ Video

links.lww.com/WNL/A353

From the Neurology and Ataxia Unit, Department of Neurology (J.L.P., L.A.D., O.G.P.B.), Universidade Federal de São Paulo; Faculdade Israelita de Ciências da Saúde Albert Einstein (L.A.D.), São Paulo, Brazil; Gardner Center for Parkinson's Disease and Movement Disorders (A.J.E.), University of Cincinnati Gardner Neuroscience Institute, OH; and Institute of Neurology (R.H.), Medical University of Vienna, Austria. 
Figure Tissue and cell-based assay for metabotropic glutamate receptor 1 (mGluR1)
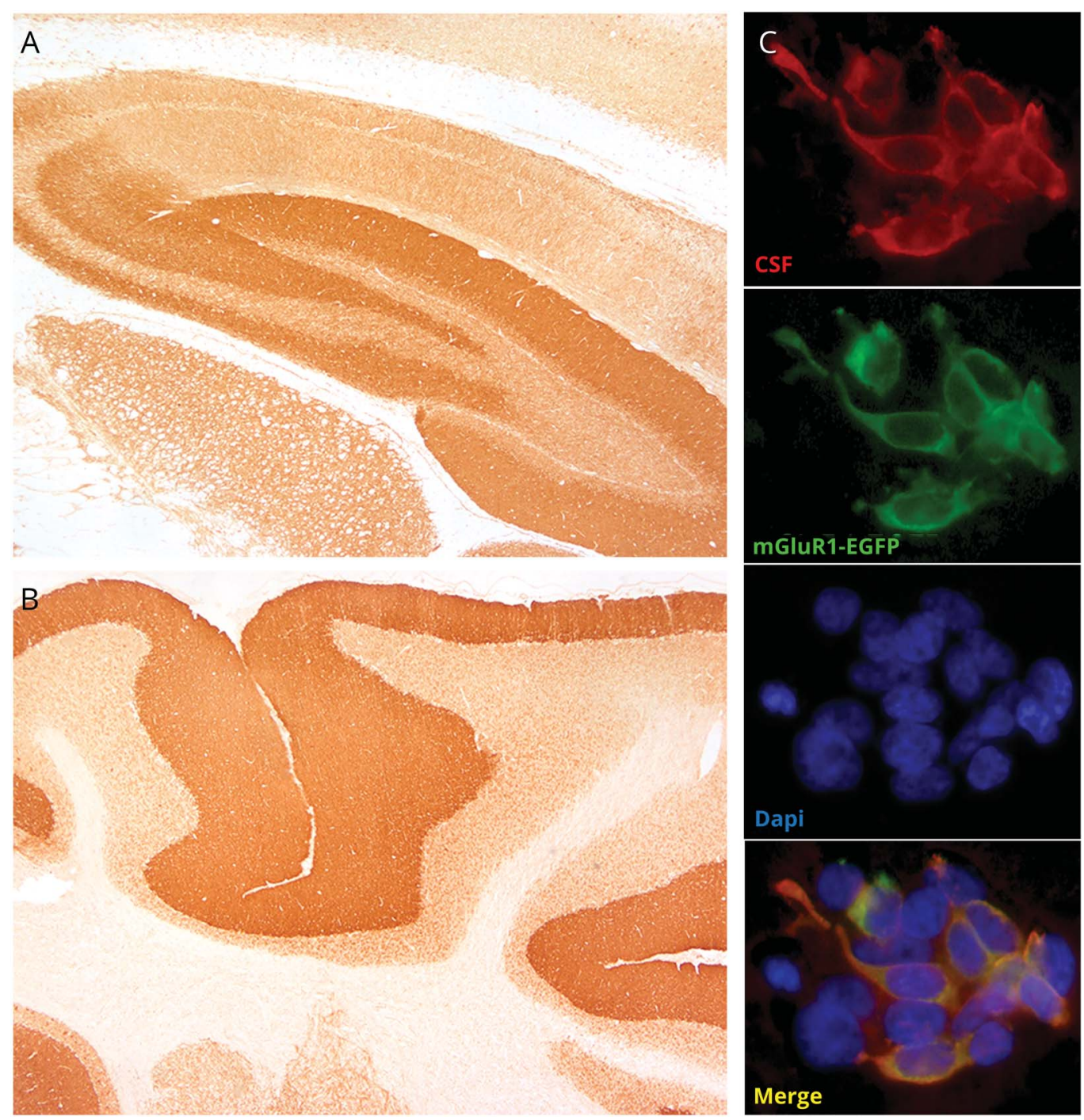

Indirect immunohistochemistry on rat brain with patient's CSF shows a neuropil staining pattern in the dentate gyrus and CA3 sector of the hippocampus (A) and molecular layer of the cerebellum (B). Antibodies of the patient are identified on HEK293T cells transfected with mGluR1-EGFP (C; red: CSF of the patient, green: mGluR1-EGFP, blue: Dapi) (A, B: ×40; C: ×400).

\section{Seeking Concussion Abstracts by May 7}

Submit your concussion research for presentation in general poster sessions during the 2018 Sports Concussion Conference July 20 through 22 at the JW Marriott in Indianapolis, IN.

Visit AAN.com/view/ConcussionConference. 


\section{Neurology}

\section{Video NeuroImages: Head titubation in anti-mGluR1 autoantibody-associated cerebellitis}

José Luiz Pedroso, Lívia Almeida Dutra, Alberto J. Espay, et al.

Neurology 2018;90;746-747

DOI 10.1212/WNL.0000000000005338

\section{This information is current as of April 16, 2018}

\section{Updated Information \& Services}

References

Citations

Subspecialty Collections

Permissions \& Licensing

\section{Reprints}

including high resolution figures, can be found at: http://n.neurology.org/content/90/16/746.full

This article cites 2 articles, 1 of which you can access for free at: http://n.neurology.org/content/90/16/746.full\#ref-list-1

This article has been cited by 1 HighWire-hosted articles: http://n.neurology.org/content/90/16/746.full\#\#otherarticles

This article, along with others on similar topics, appears in the following collection(s):

All Immunology

http://n.neurology.org/cgi/collection/all_immunology

All Medical/Systemic disease

http://n.neurology.org/cgi/collection/all_medical_systemic_disease All Movement Disorders

http://n.neurology.org/cgi/collection/all_movement_disorders Tremor

http://n.neurology.org/cgi/collection/tremor

Information about reproducing this article in parts (figures,tables) or in its entirety can be found online at:

http://www.neurology.org/about/about_the_journal\#permissions

Information about ordering reprints can be found online:

http://n.neurology.org/subscribers/advertise

Neurology ${ }^{\circledR}$ is the official journal of the American Academy of Neurology. Published continuously since 1951, it is now a weekly with 48 issues per year. Copyright () 2018 American Academy of Neurology. All rights reserved. Print ISSN: 0028-3878. Online ISSN: 1526-632X.

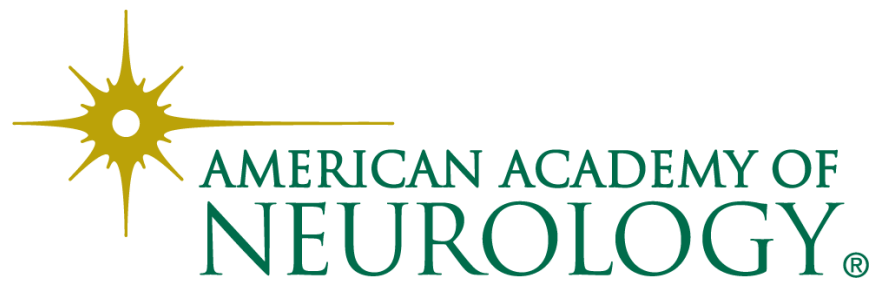

